\title{
The Use of ICT for Economic Development in the Silesian Region in Poland
}

\author{
Celina M. Olszak and Ewa Ziemba \\ University of Economics, Katowice, Poland
}

celina.olszak@ue.katowice.pl ewa.ziemba@ue.katowice.pl

\begin{abstract}
The purpose of this study is to diagnose the state of the use of Information Communication Technology (ICT), especially the Internet, in the Silesian region. The article presents the essence and attributes of knowledge-based economy (KBE). The importance of ICT in its development is stressed, especially for businesses, citizens, and administration, as the main beneficiaries of KBE. Using cross-sectional studies as a research method, we analyzed the use of ICT in such relationships as consumer-business, consumer-consumer, business-administration, and citizensadministration. In the final part we presented the conclusions based on the conducted research and made recommendations for the use of ICT in Silesia.
\end{abstract}

Keywords: knowledge-based economy, ICT in organizations, relationships in knowledge-based economy

\section{Introduction}

Creating a knowledge-based economy (KBE), in the opinion of many experts, is the only effective strategy to improve the competitiveness of countries, regions, and companies in the global market (Cooke \& Leydesdorff, 2006; Godin, 2006; Hanna, 2010, World Bank, 2009). The research results and achievements of developed countries confirm that the construction of $\mathrm{KBE}$ is associated with widespread use of information and communication technologies (ICT) (Rivard, Aubert \& Patry 2004; Roztocki \& Weistroffer, 2009a, 2009b; Tapscot \& Williams, 2006). ICT is one of the most important pillars of a $\mathrm{KBE}$, and very often the concept of $\mathrm{KBE}$ is equated with such terms as digital economy, network economy, and e-economy. The main beneficiaries of the $\mathrm{KBE}$ and ICT users are companies, public administration, and citizens at the same time. The use of ICT revolutionizes the way of conducting business, work, study, and concluding relationships.

The purpose of this study is an analysis of the ICT use, especially the Internet in the Silesian region, and particularly in the context of KBE development. We analyzed the use of ICT in relationships: citizen-administration, business-administration and citizen-business. 176 companies and 500 citizens participated in our study. Cross-sectional studies and questionnaires were used as

Material published as part of this publication, either on-line or in print, is copyrighted by the Informing Science Institute. Permission to make digital or paper copy of part or all of these works for personal or classroom use is granted without fee provided that the copies are not made or distributed for profit or commercial advantage AND that copies 1) bear this notice in full and 2) give the full citation on the first page. It is permissible to abstract these works so long as credit is given. To copy in all other cases or to republish or to post on a server or to redistribute to lists requires specific permission and payment of a fee. Contact Publisher@InformingScience.org to request redistribution permission. a research tool. The research analysis was carried out by means of the Statistical Package for the Social Sciences (SPSS) for Windows.

Our research results may be helpful in decision-taking processes to improve the use of ICT by businesses, administrations, and citizens, in particular to improve their activities and to develop relationships between them. 


\section{Literature Review}

\section{Knowledge-Based Economy Essence and Attributes}

The interest in knowledge as a factor for socio-economic development is not a new phenomenon. Knowledge has long been the subject of numerous studies. Its importance began to be noticed after the Second World War. Even before that, it had been noticed by the Nobel prizewinner in economics F.A. Hayek, who in his work Economics and Knowledge from 1937 and The use of Knowledge in Society from 1945 perceived the information as a commodity (Hayek, 1937, 1945). Relatively quickly the notion that the collection and dissemination of information create a new quality of the economy was shared by other researchers.

In 1963, T. Umesao introduced the term "information society", and in 1973 D. Bell introduced the concept of postindustrial society development. According to the authors the transition from an industrial to post-industrial economy meant primarily (Bell, 1973):

- the dominance of service sector in the economy;

- the fundamental importance of knowledge as a source of innovation;

- attitude towards the development of ICT;

- creating new "intellectual technology" as a basis for political and social decision-making;

- growing importance of professionals and researchers in the occupational structure.

Shortly, in an interesting way the socio-economic developments were described by A. Toffler (1980); metaphorically he compared them to three waves: agrarian, industrial, and postindustrial. In the last wave, the basic raw material is information, and the ability to process this information becomes an important skill.

Toffler forecasts were in line with what, several years later, P. Drucker suggested. The author of Post-Capitalist Society stated that the primary economic resources are no longer capital, natural resources, or manpower, but it is knowledge. The ruling groups are knowledge specialists and entrepreneurs who can use knowledge in practical activity (Drucker, 1993).

Five megatrends have been introduced by J. D. Skyrme (1999) to describe the features of the knowledge-based economy by assuming that information and knowledge pervade in all sectors of industry as well as in all new industries based around them. The features observable in the KBE are:

- every industry is in the process of becoming more knowledge intensive;

- smart products, that are based on the use of information or knowledge, are present and provide better functionality or service, moreover, premium prices can be charged;

- higher information to weight ratios exists in this economy. For example, the financial value of United States exports has increased twenty times more, while the physical weight of goods exported is about the same;

- value in intangibles: it means that the market value of most companies is several times higher than the value of their physical assets as recorded in their balance sheets. This is basically due to the role of intangibles, such as know-how, information systems, patents and brands whose value is not recorded by traditional accounting methods;

- trade in intangibles grows in these economies.

In the development of knowledge-based economy and in building its foundations such organizations as: OECD, World Bank and the European Union are taking part. 
According to the OECD, the knowledge-based economy is the economy that is based on the production, distribution, and use of knowledge and information (OECD, 1996), for which it is necessary to use ICT. Knowledge is regarded as a product and a factor of production determining innovation, productivity, and competitiveness (Castells, 1997).

The World Bank, explaining the concept of KBE, draws attention to its basic pillars, which include innovation, education, ICT, economic, and institutional environment (World Bank, 2011). They are most often the subject to evaluation and establish the base for the development indicators of KBE in different countries.

Reflecting on the essence of KBE, it is impossible to overlook its one particular characteristic, which is networking. KBE is by some writers identified with the concept of the network economy. The network generates a multidimensional and hybrid relationships and linkages in the economy, and synergy is the key to the success of the economy and the operating organizations (Castells \& Himanen, 2002).

Many authors describing the nature of $\mathrm{KBE}$ emphasize that its development is associated with new professions and skills connected with the acquisition, processing of information, and creation of new knowledge. These competencies are closely associated with the use of ICT, which provides the basis for the development of innovative products and services (Tapscott \& Williams, 2006).

Analyzing KBE, it's hard not to notice that it also embodies the change of power and industrial relations, organizational, and cultural transformations. The key features of KBE and, at the same time, differences in relation to the traditional economy are shown in Table 1.

Table 1: The main differences between KBE and traditional economy

\begin{tabular}{|l|l|l|}
\hline \multicolumn{1}{|c|}{$\begin{array}{c}\text { Characteristics of } \\
\text { an economy }\end{array}$} & \multicolumn{1}{c|}{$\begin{array}{c}\text { Traditional economy } \\
\text { (industrial) }\end{array}$} & \multicolumn{1}{|c|}{ Knowledge-based economy } \\
\hline Resources & Tangible & $\begin{array}{l}\text { Intangible (knowledge, informa- } \\
\text { tion) }\end{array}$ \\
\hline People (employees) & Source of cost & Investment \\
\hline Authority & $\begin{array}{l}\text { Depends on the level occupied in } \\
\text { the organization }\end{array}$ & $\begin{array}{l}\text { Depends on the possessed skills, } \\
\text { knowledge and reputation }\end{array}$ \\
\hline Management style & Orders and control & Participatory \\
\hline Organizational structure & Hierarchical, centralized & $\begin{array}{l}\text { Network, the flattering of organ- } \\
\text { izational structures }\end{array}$ \\
\hline Strategy & Competition-driven & Cooperation-driven \\
\hline Organizational culture & Based on obedience & Based on trust \\
\hline Market value & $\begin{array}{l}\text { Depends on the possession of fi- } \\
\text { nancial and fixed assets }\end{array}$ & Depends on the intellectual capital \\
\hline Motivation & $\begin{array}{l}\text { Primarily through financial incen- } \\
\text { tives }\end{array}$ & Through the external satisfaction \\
\hline Consumer relationships & One-way through the market & Interactive, through collaboration \\
\hline Change & Thread & Opportunity \\
\hline Development & Linear, foreseeable & Chaotic, unpredictable \\
\hline $\begin{array}{l}\text { The use of technology, ICT } \\
\text { especially }\end{array}$ & Important & Indispensible \\
\hline Dominant sector & Heavy industry & $\begin{array}{l}\text { Services, data processing, knowl- } \\
\text { edge }\end{array}$ \\
\hline
\end{tabular}

Summing up, the KBE means changing power relationships and labor along with economic, social, educational, organizational, and cultural transformations (Araya \& Peters, 2010; David \& Foray, 2002; Kassicieh, 2010; Leydesdorff, 2006; Melnikas \& Samulevičius, 2009). Hands-on 
experience and research work show that the KBE development is determined by the development of education and improvement of human competences, strengthening of innovative potential, economic, and conductive institutional policy (World Bank, 2009, 2011). Development and efficient use of ICT is the strong determinant of KBE development (Cohendet \& Stojak, 2005, EinDor, Myers, \& Raman, 2004; Goeransson \& Soederberg, 2005; Hanna, 2009; Steinmueller, 2002). New ICT, especially the Internet, bring new opportunities and then concentrate on core competencies, specialize, and increase trade and investment flows. ICT improves activities of businesses, administrations, and citizens and develops relationships between them.

\section{ICT in the Development of the Various Relationships in the Knowledge-Based Economy}

As it has been mentioned earlier, ICT is one of the pillars of a KBE and is of strategic importance for the socio-economic development. This is reflected, among others, in:

- ICT helps to improve work efficiency and reduce operating costs;

- ICT generates new jobs, associated with broader information processing;

- ICT attracts investors and strategic partners, and improves the attractiveness and credibility of individual regions;

- ICT stimulates the formation of companies producing hardware and software;

- ICT infrastructure and ICT sector as a whole have strong links with related sectors, which can grow resiliently.

It turns out that ICT infrastructure is the basis for efficient development of relations between the major KBE stakeholders, i.e., business (companies), administration, and citizens/consumers (Figure 1). The most important types of relationship include B2B (business-to-business), B2E (business-employee), E2B (employee-business), B2C (business-to-consumer), C2B (consumer-tobusiness), $\mathrm{C} 2 \mathrm{C}$ ( consume-to-consumer), B2A (business-to-administration), A2B (administrationto-business), C2A (consumer-to-administration), A2C (administration-to-consumer), and A2A (administration-to-administration) (Anumba \& Ruikar, 2008; Meier \& Stormer, 2009).

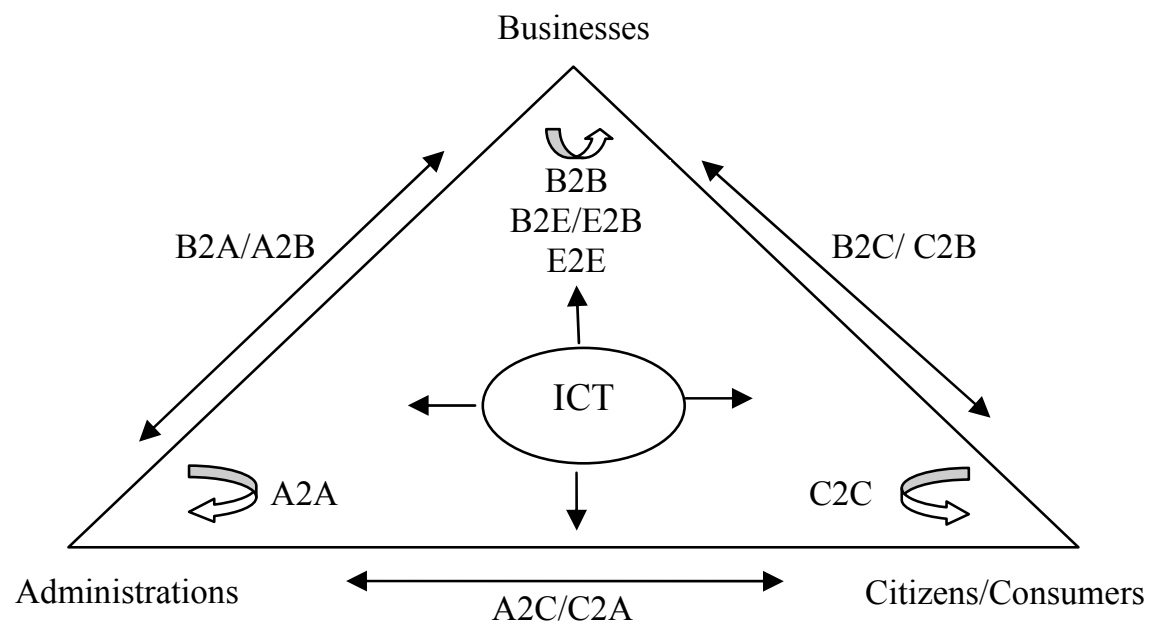

Figure 1. ICT in the development of key relationships in KBE

B2B relationships exist between the organizations, which are companies, institutions, foundations, etc. The transactions may involve many areas of economic activity, for example, orders from suppliers, sales to sales representatives or distributors of goods, products or services, an order directed by the company to a bank that serves it, wholesale transactions between companies on the commodity exchange, etc. 
The B2C model embraces actions of an organization in the context of a relationship with a single end-user or a group of consumers. Such activities include widely perceived promotion and business information, retail, individual customer service provided by a bank, or purchase of an insurance policy or tour.

Within the frame of $\mathrm{C} 2 \mathrm{~B}$ model customers interact with companies. Clients often turn to the company with questions and even offer the company the conditions under which a transaction can be concluded. What's more, there are also contacts of whole consumer groups with companies, for example, various types of lists and discussion forums.

The B2E model applies to any business relations with its employees. Symmetrical in relation to it is the E2B model which describes a reciprocal relationship. Equally frequent are the relationships between employees (E2E). These models indicate links within the organization, links between organizational units, as well as relationships between individual employees. In this way, communication develops and the ability to work collaboratively, including the facilitation of knowledge sharing and cooperation. Within these relationships electronic training is conducted.

Relationships of $\mathrm{C} 2 \mathrm{C}$ type imitate interactions that occur between different consumers or consumer groups. Examples of such relationships may be even discussion groups and forums where consumers can meet and exchange their opinions. Also, synchronous communications (in real time - for example through chat or IM) and even e-mails are typical activities of C2C model. This model was used in the construction of online auctions in which different people may enter into buy-sell transactions.

B2A relationships allow for a quick and efficient exchange of information between companies and various agencies of government. Such an exchange of information primarily applies to taxes and insurance, government tenders, or e-mail communication with a government. An example of the reverse relationship (A2B) may be calls for tenders.

Relationships of type $\mathrm{C} 2 \mathrm{~A}$ and $\mathrm{A} 2 \mathrm{C}$ mean the bilateral relationship between the consumer (an individual) and the offices of government. They concern mainly the accounts of taxpayers with tax offices and the insured with insurance institutions.

The A2A model involves the exchange of data and information within the same offices of local and governmental administration.

\section{ICT in Knowledge-Based Economy in the Light of Selected Documents of the European Union}

The European Union, being aware of the significance of ICT in the development of the economy and the entire society, has taken a number of steps to commence the program for construction of the information society and KBE. The first official document, confirming the EU's interest in the information society's issues was a report by M. Bangemann (1994). It presents the recommendations for strengthening the EU's position in the technological race on the international arena. In 2000, the European Council at its meeting in Lisbon adopted the strategy for the construction of the knowledge-based economy by 2010. This initiative was expected to contribute to the economic growth, job generation, and better social coherence within the EU.

In Poland, using $e$ Europa as a model, the $e$ Polska initiative was created - the information society development strategy for Poland in the years 2001-2006; subsequently it was expanded to cover the period of 2007-2013. The $e$ Polska document is a collection of individual strategies from all the areas concerned with the construction and implementation of the information society and KBE (Olszak \& Ziemba, 2009). The document takes into account the priorities resulting from assumptions of the Lisbon Strategy and initiatives eEurope. An Information Society for All (Europa, 2000) and its continuation - i2010. A European Information Society for Growth and Em- 
ployment (Europa, 2005) The paper $e$ Polska defines the development of mission in the information society in Poland until 2013, which stresses the importance of information and knowledge and application of ICT for harmonious economic, social, and personal development. Based the adopted mission of the information society strategic courses of action have been designated for:

- people (the area of an individual) - to accelerate the social and intellectual capital development among Polish people through the ICT use;

- business entities (the area of economy) - increase of efficiency, innovation and competitiveness of companies, and thus the Polish economy on the global market and to facilitate communication and cooperation between companies through the ICT use;

- public administration ( the area of the state ) - increase of accessibility and efficiency of government services through the use of ICT to rebuild the internal processes of administration and the way of providing services (MSWiA, 2008).

Within the frame of $e$ Polska strategy general guidelines have also been specified as to the functionality of ICT. It is emphasized that it is necessary to take the following actions:

- development of publicly available electronic services in public administration, business and health care;

- stimulation of development and creation of Polish digital resources on the Internet, particularly resources that are important for the competitive position of Polish economy in the EU, the development of entrepreneurship and greater social and economic cohesion;

- development of state ICT infrastructure and especially providing universal broadband access to the Internet and e-commerce services;

- development of skills necessary for active and creative participation in information society services, in particular the adaptation of educational system for KBE needs(MNiI, 2005).

\section{Research Methodology}

Poland, especially the Silesian region, is clearly marked by a scarcity of studies on the use of ICT in business, administration, and consumers/citizens relations. This fact prompted the authors to conduct empirical research in this field. The study took place in late 2009 and 2010. 176 companies and 500 citizens were the participants in our study. The selection of respondents in the sample was purposeful. The sample selection criterion was the fact of the Internet use by citizens and the possession of e-mail address by the company.

Cross-sectional studies and a questionnaire (Appendix A, Appendix B) were used as a research tool. The former represents a quantitative approach (positivistic methodology) that is preferable wherever the topic of inquiry is well-defined, the reality is objective and singular, and the researcher is independent from that being researched (Collis \& Hussey, 2003; Creswell, 1994). Furthermore, J.K. Smith (1983, p.10) argues that "in quantitative research facts act to constrain our beliefs." Also, cross-sectional studies are conducted when there are constraints regarding time and resources. The data is collected just once, over a short period of time, before it is analyzed and reported. Thus, cross-sectional studies take a snapshot of an on-going situation (Collis \& Hussey, 2003). Therefore, by conducting cross-sectional studies, we are better able to capture how citizens, business and public administration use various ICT.

The research was conducted in the Upper Silesia, which is one of the most dynamically developing Polish regions. 4.64 million people live in the Silesian region, or 12.2\% of the population. The value of gross domestic product (GDP) in the Silesian Voivodship equals 167,948 million of Polish zloty, which represents over $13 \%$ of the national GDP and ranks the voivodship in the sec- 
ond place in the country. At the end of 2009 there were 430,578 registered business entities, out of which $96.2 \%$ are private companies. The biggest group constituted micro-companies 404,813. There were also 21,528 small companies, 3,623 medium, and 614 large. The region has more than $17 \%$, on a national scale, of companies with foreign capital. The region is characterized by the highest employment in the country $(11.9 \%$ of domestic employment in national economy). Not without reason the Silesian region is regarded as a strategic region for investors, both domestic and foreign. Still, its further development and simultaneously entering the canon of the $\mathrm{KBE}$, are certainly determined by increasingly effective use of ICT by companies, public administration, and citizens.

Most of the surveyed companies were micro-companies (employing up to 9 employees), which accounted for nearly $45 \%$. Every fourth company was a small company (10 to 49 employees), less than $19 \%$ of the sample were medium-sized companies (from 50 to 249 employees) and large companies (over 250 employees), which accounted for $12 \%$ of all respondents. The leading business profile among surveyed companies was service. Manufacturing and trade companies accounted for $23 \%$ and $22 \%$, respectively. However, mixed-type companies accounted for only about $7 \%$. Nearly every third company carried out the activity on the domestic or international market, and every sixth in the regional one. Over $22 \%$ of companies focused their activities exclusively on the local market. In our study one employee per company was surveyed. The answers were mainly provided by owners and co-owners of companies along with their Chief Information Officers and Chief Executive Officers.

The aim of the research in companies was primarily to diagnose the level of ICT use to engage in the following relationship:

- communication and collaboration within the organization (B2E, E2B, E2E);

- communication and collaboration with business partners (B2B);

- communication and cooperation with public administration (B2A, A2B).

Additionally, the companies were analyzed on the ground of the degree of ICT utilization in their primary and support activities as well as analytical ones. The primary activities include inbound logistics, operations (production), outbound logistics, marketing and sales (demand), and services (maintenance). The support activities include administrative infrastructure management, human resource management, technology (R\&D), and procurement (Porter, 1996).

On the other hand, the aim of the research embracing the citizens was the diagnosis of the ICT use by the citizens in the relationships with businesses and administration $(\mathrm{C} 2 \mathrm{~B}, \mathrm{~B} 2 \mathrm{C}, \mathrm{A} 2 \mathrm{C}$, C2A). 500 citizens of the Upper Silesia participated in the survey. The average age of citizens was men - 47 years, women - 45 years. Men often held a degree in secondary (39.1\%) or professional education (37.7\%) and most were working (88.5\%). Among the surveyed women, $51 \%$ had secondary education and $24.6 \%$ higher. $72.7 \%$ of women were economically active.

The research analysis was carried out by means of the Statistical Package for the Social Science (SPSS) for Windows - comprehensive statistical software used for data analyses and data management.

\section{Findings}

\section{The Diagnosis of ICT and the Internet Use in the Silesian Companies}

The study results have revealed that in the area of communication and cooperation within a company the Internet is mainly used for correspondence (64.9\%) (Table 2). Other processes and tasks 
are supported poorly. These have to do with issuing instructions to departments (about 26\%), the exchange of knowledge (about 17\%), performing routine procedures (about 22\%), and cooperation of staff (about $33 \%$ ) and a social integration (10\%). Only a few companies have confirmed that in order to solve these problems they use specialized computer software. The fact that many companies communicate with employees by the use of traditional paper and pencil and do not see the need for cooperation among employees raises a concern.

Table 2: The use of ICT in E2B/B2E and E2E relations (\% of the companies sampled)

\begin{tabular}{|c|c|c|c|c|c|}
\hline \multirow[b]{2}{*}{ Specification } & \multirow{2}{*}{$\begin{array}{l}\text { The issue } \\
\text { does not } \\
\text { concern } \\
\text { my com- } \\
\text { pany }\end{array}$} & \multirow[b]{2}{*}{$\begin{array}{l}\text { The com- } \\
\text { pany uses } \\
\text { the Internet }\end{array}$} & \multicolumn{2}{|c|}{ The company uses } & \multirow{2}{*}{$\begin{array}{l}\text { The com- } \\
\text { pany is not } \\
\text { capable of } \\
\text { dealing with } \\
\text { the issue }\end{array}$} \\
\hline & & & $\begin{array}{l}\text { paper and } \\
\text { pencil }\end{array}$ & $\begin{array}{l}\text { computer and } \\
\text { software }\end{array}$ & \\
\hline Correspondence & 16.6 & 64.9 & 7.9 & 9.3 & 1.3 \\
\hline Passing official orders & 26.1 & 29.9 & 29.3 & 14.0 & 0.6 \\
\hline $\begin{array}{l}\text { Exchange of knowledge and } \\
\text { experience }\end{array}$ & 17.3 & 28.7 & 34.0 & 16.7 & 3.3 \\
\hline $\begin{array}{l}\text { Conducting routine proce- } \\
\text { dures (e.g. business trips, hol- } \\
\text { iday leave applications) }\end{array}$ & 22.1 & 21.4 & 38.3 & 18.2 & 0.0 \\
\hline Horizontal cooperation & 32.5 & 23.6 & 31.8 & 11.5 & 0.6 \\
\hline Vertical cooperation & 33.8 & 29.9 & 26.0 & 9.7 & 0.6 \\
\hline Social integration & 55.5 & 10.3 & 22.6 & 6.5 & 5.2 \\
\hline
\end{tabular}

Analyzing the area of communication and cooperation with business partners, it can be noted that most of problems in this field are solved by using the Internet (Table 3). It is primarily used for searching for business partners and conducting negotiations $(61.9 \%)$, sending and receiving offers $(78.6 \%)$, ordering $(64.2 \%)$, receipt of orders $(63.1 \%)$, issuing invoices $(17.7 \%)$, receiving invoices $(21.7 \%$ indications), settlement of payables $(67.5 \%)$, settlement of receivables $(67.3 \%)$, the exchange of experience and knowledge (44.9\%). The exception here is the issuing and receiving of invoices, as most businesses still prefer paper versions but for their preparation they use computer software.

Table 3: The use of ICT in B2B relations (\% of the companies sampled)

\begin{tabular}{|c|c|c|c|c|c|}
\hline \multirow[b]{2}{*}{ Specification } & \multirow{2}{*}{$\begin{array}{l}\text { The issue } \\
\text { does not } \\
\text { concern } \\
\text { my com- } \\
\text { pany }\end{array}$} & \multirow[b]{2}{*}{$\begin{array}{l}\text { The company } \\
\text { uses the In- } \\
\text { ternet }\end{array}$} & \multicolumn{2}{|c|}{ The company uses } & \multirow{2}{*}{$\begin{array}{l}\text { The com- } \\
\text { pany is not } \\
\text { capable of } \\
\text { dealing } \\
\text { with the } \\
\text { issue }\end{array}$} \\
\hline & & & $\begin{array}{c}\text { paper and } \\
\text { pencil }\end{array}$ & $\begin{array}{l}\text { computer and } \\
\text { software }\end{array}$ & \\
\hline $\begin{array}{l}\text { Searching for business part- } \\
\text { ners and negotiations }\end{array}$ & 20.0 & 61.9 & 14.2 & 2.6 & 1.3 \\
\hline Sending and receiving offers & 9.4 & 78.6 & 5.7 & 6.3 & 0.0 \\
\hline Ordering & 13.2 & 64.2 & 12.6 & 10.1 & 0.0 \\
\hline Receipt of orders & 13.4 & 63.1 & 14.0 & 9.6 & 0.0 \\
\hline Issuing invoices & 13.3 & 17.7 & 20.3 & 48.7 & 0.0 \\
\hline Receiving invoices & 14.6 & 21.7 & 36.3 & 27.4 & 0.0 \\
\hline Settlement of payables & 12.1 & 67.5 & 10.8 & 7.6 & 1.9 \\
\hline Settlement of receivables & 10.1 & 67.3 & 13.2 & 8.2 & 1.3 \\
\hline $\begin{array}{l}\text { The exchange of experience } \\
\text { and knowledge }\end{array}$ & 21.2 & 44.9 & 23.1 & 9.6 & 1.3 \\
\hline
\end{tabular}


The diagnosis of communication and cooperation with administrations shows that more than a half of the companies surveyed use the Internet to adjust the tax (56.8\%) and insurance liabilities $(59.9 \%)$ and to send a declaration of insurance (50.3\%). 65\% of companies use the Internet Public Information Bulletin. However, only to a very limited degree are internet technologies used for communication with customs authorities, the city authorities (municipalities, counties), or the exchange of correspondence with the Inland Revenue Offices and ZUS (a social insurance institution). Many of the processes concerning communication with the administration are conducted by using traditional means, i.e., pencil and paper (Table 4).

Table 4: The use of ICT in A2B/B2A relations (\% of the companies sampled)

\begin{tabular}{|l|r|r|r|r|r|}
\hline & \multicolumn{1}{|c|}{$\begin{array}{c}\text { The issue } \\
\text { does not } \\
\text { concern } \\
\text { my com- } \\
\text { pany }\end{array}$} & \multirow{2}{*}{$\begin{array}{c}\text { The com- } \\
\text { pany uses } \\
\text { the Internet }\end{array}$} & \multicolumn{2}{|c|}{$\begin{array}{c}\text { The company uses } \\
\text { paper and } \\
\text { pencil }\end{array}$} & $\begin{array}{c}\text { The com- } \\
\text { pany is not } \\
\text { capable of } \\
\text { dealing } \\
\text { with the } \\
\text { issue }\end{array}$ \\
\hline $\begin{array}{l}\text { Sending tax return forms to tax } \\
\text { authorities }\end{array}$ & 11.9 & 37.1 & 35.2 & 15.7 & 0.0 \\
\hline $\begin{array}{l}\text { Exchange of correspondence } \\
\text { with tax authorities }\end{array}$ & 13.8 & 24.5 & 43.4 & 17.6 & 0.6 \\
\hline Settling tax liabilities & 11.6 & 56.8 & 22.6 & 9.0 & 0.0 \\
\hline $\begin{array}{l}\text { Communication with customs } \\
\text { authorities }\end{array}$ & 62.3 & 10.4 & 18.8 & 3.9 & 4.5 \\
\hline Sending ZUS returns & 13.4 & 50.3 & 25.5 & 10.8 & 0.0 \\
\hline $\begin{array}{l}\text { Exchange of correspondence } \\
\text { with ZUS }\end{array}$ & 13.0 & 29.2 & 42.9 & 14.9 & 0.0 \\
\hline $\begin{array}{l}\text { Settlement of social insurance } \\
\text { liabilities }\end{array}$ & 10.2 & 59.9 & 22.9 & 7.0 & 0.0 \\
\hline $\begin{array}{l}\text { Communication with city, mu- } \\
\text { nicipal or county offices }\end{array}$ & 22.2 & 19.0 & 46.2 & 12.0 & 0.6 \\
\hline $\begin{array}{l}\text { Access to the Internet Public } \\
\text { Information Bulletin }\end{array}$ & 25.0 & 65.0 & 7.5 & 1.9 & 0.6 \\
\hline
\end{tabular}

Technologies that are most often used by companies for internal communication and cooperation with business partners and public administration are email (99.4\%), electronic bulletins and newsletters $(80.4 \%)$, instant messengers $(65 \%)$, intranet $(62.9 \%)$, forums $(50 \%)$, social networking sites $(40.5 \%)$, and teleconferencing $(34 \%)$.

The development of economy requires companies to use the Internet in primary and support areas of activity. Use of ICT in purchasing, sales, inventory service, human resources, payroll, marketing, finance and accounting, manufacturing, and transport is shown in Table 5. In the surveyed companies the Internet is used mainly in marketing activities (58.9\%) and supply (51.2\%). 31.5\% of businesses use the Internet in the sales processes. Specialized software supports finance and accounting for $44.2 \%$, staff records management (38.9\%), and payroll processing (35.8\%). Less than half of the companies use the integrated ERP systems (Enterprise Resource Planning). Less frequently document management systems are used (29.7\%), competency management systems $(12.5 \%)$, and workflow systems $(10.9 \%$. In order to run the primary and support operations, most of organizations use conventional means, such as paper and pencil. 
Table 5: The use of ICT and the Internet in the primary and support activities (\% of the companies sampled)

\begin{tabular}{|c|c|c|c|c|c|}
\hline \multirow[b]{2}{*}{ Specification } & \multirow{2}{*}{$\begin{array}{l}\text { The issue } \\
\text { does not } \\
\text { concern } \\
\text { my com- } \\
\text { pany }\end{array}$} & \multirow{2}{*}{$\begin{array}{l}\text { The com- } \\
\text { pany uses } \\
\text { the Internet }\end{array}$} & \multicolumn{2}{|c|}{ The company uses } & \multirow{2}{*}{$\begin{array}{l}\text { The com- } \\
\text { pany is not } \\
\text { capable of } \\
\text { dealing } \\
\text { with the } \\
\text { issue }\end{array}$} \\
\hline & & & $\begin{array}{l}\text { paper and } \\
\text { pencil }\end{array}$ & $\begin{array}{l}\text { computer and } \\
\text { software }\end{array}$ & \\
\hline Purchasing & 21.0 & 51.2 & 17.3 & 10.5 & 0.0 \\
\hline Sales & 22.8 & 31.5 & 17.9 & 25.9 & 1.9 \\
\hline Inventory service & 43.0 & 12.0 & 13.3 & 31.0 & 0.6 \\
\hline Human Resources & 24.1 & 19.8 & 17.3 & 38.9 & 0.0 \\
\hline Payroll & 18.5 & 31.5 & 14.2 & 35.8 & 0.0 \\
\hline Marketing & 22.7 & 58.9 & 5.5 & 12.3 & 0.6 \\
\hline Finance and accounting & 17.2 & 25.2 & 13.5 & 44.2 & 0.0 \\
\hline Manufacturing & 64.4 & 6.9 & 15.6 & 13.1 & 0.0 \\
\hline Transport & 62.1 & 14.3 & 18.0 & 5.0 & 0.6 \\
\hline
\end{tabular}

The research has confirmed that the Silesian companies do not attribute much importance to the use of ICT while performing a more complex economic and financial analysis (Table 6). Over $50 \%$ of the companies do not appreciate the quality control and business audit processes. $46.8 \%$ of the organizations do not carry out the analysis of investment projects. Quite a number of organizations (54.4\%) use the Internet for the market, product/service and other analysis (economic, political, social). There is limited use of specialized software for the realization of the above tasks and particularly for word processing $(98.8 \%)$, spreadsheets $(91.9 \%)$, and databases $(46.8 \%)$. Data warehousing has been used by only $20 \%$ of companies. But even they do not take a full advantage of this technology, since only $4.7 \%$ of companies confirmed the use of multidimensional OLAP analysis and business intelligence tasks. Data mining tools (e.g., Statistica, SPSS, Oracle Data Mining) are used by only $11.7 \%$ of companies.

Table 6: The use of ICT for economic and financial analysis (\% of the companies sampled)

\begin{tabular}{|c|c|c|c|c|c|}
\hline \multirow[b]{2}{*}{ Specification } & \multirow{2}{*}{$\begin{array}{l}\text { The issue } \\
\text { does not } \\
\text { concern } \\
\text { my com- } \\
\text { pany }\end{array}$} & \multirow{2}{*}{$\begin{array}{l}\text { The com- } \\
\text { pany uses } \\
\text { the Internet }\end{array}$} & \multicolumn{2}{|c|}{ The company uses } & \multirow{2}{*}{$\begin{array}{l}\text { The com- } \\
\text { pany is not } \\
\text { capable of } \\
\text { dealing } \\
\text { with the } \\
\text { issue }\end{array}$} \\
\hline & & & $\begin{array}{l}\text { paper and } \\
\text { pencil }\end{array}$ & $\begin{array}{l}\text { computer and } \\
\text { software }\end{array}$ & \\
\hline Quality control & 55.7 & 8.2 & 23.4 & 11.4 & 1.3 \\
\hline Business processes audit & 57.4 & 11.6 & 14.2 & 12.3 & 4.5 \\
\hline Investments audit & 46.8 & 19.9 & 12.8 & 18.6 & 1.9 \\
\hline Market analysis & 29.5 & 54.5 & 5.8 & 9.0 & 1.3 \\
\hline Product/service analysis & 29.9 & 47.4 & 9.1 & 12.3 & 1.3 \\
\hline $\begin{array}{l}\text { Environmental analy- } \\
\text { sis(economic, political, social) }\end{array}$ & 33.5 & 51.6 & 8.4 & 3.2 & 3.2 \\
\hline
\end{tabular}

The conducted research has shown that most companies do not have an electronic signature. Every third company has a qualified electronic signature, and only $6 \%$ have a non-qualified sig- 
nature. The unqualified signature is mostly used by small firms (one in ten companies). Mainly these are micro-companies which do not possess electronic signatures. More than half of the surveyed companies cited a lack of need as a reason for not using an electronic signature. Every third reason given was the low prevalence of use, and one in six companies has no electronic signature due to its high price.

The research has revealed that companies with an electronic signature use it primarily for communication with the Social Insurance Institution (ZUS) (almost 85\%). Less than 40\% of surveyed companies use it to communicate with tax authorities, and every fourth company to communicate with banks and contractors. Every tenth company uses e-signature in correspondence with city, municipal, county offices (Table 7).

Table 7: The use of electronic signatures in companies (\% of the companies sampled)

\begin{tabular}{|l|r|}
\hline Specification & Total \\
\hline For communication with banks & 25.4 \\
\hline For communication with ZUS & 84.7 \\
\hline For communication with tax authorities & 37.3 \\
\hline For communication with city, municipal, county offices & 10.2 \\
\hline For communication with contractors & 23.7 \\
\hline Other (PFRON, electronic auctions, Internet auctions, state administration) & 6.8 \\
\hline
\end{tabular}

The companies agree that they are faced with the need to overcome barriers to implementation and application of ICT. These include the lack of financial resources (36\%), lack of information about the existence of relevant services (36\%), lack of appropriate services (33\%), lack of skills of workers $(27 \%)$, and lack of technological conditions $(21 \%)$.

\section{The Diagnosis of the Internet Use by Citizens in the Silesian Region}

The research has shown that $91 \%$ of citizens use the Internet every day, and the remaining a few times a week. Most people use the Internet at home (99\%), less at work $(22 \%)$ and at school or university (17\%).

Most often the citizens use the Internet to communicate with friends and family. Over $90 \%$ use email, over $70 \%$ of social networking sites, with almost half of forums and discussion groups. Search engines are used by all citizens surveyed; the e-map is used by almost $70 \%$ of the citizens.

The study shows that $85 \%$ of citizens make purchases over the Internet. They most often buy books, clothes, mobile phones and accessories, shoes, automotive articles, cosmetics, household appliances and audio / video, computers and parts for computers, tickets to cultural, sporting events, and transport, jewelry, DVDs, music and movies, computer software. The vast majority does their shopping on the Internet occasionally (52.2\%) or several times a month (28.2\%).

Over $85 \%$ of the population use the Internet to get information about cultural events and entertainment, and a little less to make a use of information on tourism services (80.4\%). Also a lot of people look for jobs on the Internet (71.8\%). More than half of citizens use the banking and financial services. And less than half look for information about training to improve skills $(41.8 \%)$ and information about health care services $(42.6 \%)$. It is highly unusual for citizens to benefit from training sites $(18.4 \%)$ and use them in order to provide work for an employer $(11.6 \%)$. The data on the Internet use by citizens are presented in Table 8. 
Table 8: The use of the Internet in $\mathrm{C} 2 \mathrm{~B} / \mathrm{B} 2 \mathrm{C}$ relations (\% of the citizens sampled)

\begin{tabular}{|l|r|r|r|}
\hline \multicolumn{1}{|c|}{ Service } & \multicolumn{1}{|c|}{ Internet use } & \multicolumn{1}{c|}{ No Internet use } & No answer \\
\hline Shopping & 85.0 & 11.0 & 4.0 \\
\hline Information on medical services & 42.6 & 55.8 & 1.6 \\
\hline Tourist information & 80.4 & 19.6 & 0.0 \\
\hline Banking and finance & 53.0 & 45.6 & 1.4 \\
\hline Legal advice & 20.0 & 77.4 & 2.6 \\
\hline $\begin{array}{l}\text { Information on cultural and entertain- } \\
\text { ment events }\end{array}$ & 85.6 & 14.4 & 0.0 \\
\hline $\begin{array}{l}\text { Information about transport communi- } \\
\text { cation }\end{array}$ & 69,4 & 26.6 & 4.0 \\
\hline $\begin{array}{l}\text { Vocational and skills improving train- } \\
\text { ings }\end{array}$ & 18.4 & 80.4 & 1.2 \\
\hline $\begin{array}{l}\text { Information on vocational and skills } \\
\text { improving trainings }\end{array}$ & 41.8 & 56.8 & 1.4 \\
\hline Provision of labour & 11.6 & 85.8 & 2.6 \\
\hline Information on job opportunities & 71.8 & 28.0 & 0.2 \\
\hline
\end{tabular}

In relations with the administration, $24 \%$ of citizens do not use the Internet. More than a half use the Internet occasionally (one - two times a year), while others use e-services slightly more often (several times a month or week). More detailed questions helped to assess the nature of the relationship with the civil administration. It turned out that nearly $75 \%$ of people use the Internet to settle an official matter, obtain information from the office, or download the forms. Approximately $12 \%$ of people send information or forms for offices via the Internet. Only about $14 \%$ of citizens comprehensively resolve the problem at the office by electronic means (Table 9).

Table 9: The use of the Internet in $\mathrm{C} 2 \mathrm{~A} / \mathrm{A} 2 \mathrm{C}$ relations (\% of the citizens sampled)

\begin{tabular}{|l|c|}
\hline Type of public e-service & Total \\
\hline Gaining information from the office & 73.2 \\
\hline Passing information to the office & 12.9 \\
\hline Downloading application forms from the office & 72.7 \\
\hline Sending forms to the office & 12.3 \\
\hline Comprehensive electronic way of settling a master & 14.4 \\
\hline Official matter monitoring & 36.7 \\
\hline
\end{tabular}

The use of public e-services is very often determined by the possession of e-signature. Unfortunately, the vast majority of citizens in the Silesian region do not have such a signature. Only 9 persons among the respondents (less than 2\%) have the qualified and the other 9 persons have an unqualified signature. Among the citizens who have the electronic signature, less than $65 \%$ of them use it. The vast majority of respondents did not have a signature because they see no such need (almost 90\%). Every sixth respondent as the reason for the absence of e-signatures have pointed to low prevalence in the use of such a signature, and for less than $7 \%$ of respondents costs of obtaining an electronic signature are too high. 
The study also revealed the barriers that prevent the use of the Internet in relations of citizens with business and public administration. These include: the lack of information about the existence of relevant services (36\%), lack of adequate services (33\%), lack of literacy (27\%), lack of technological conditions (21\%) and high costs (computer, Internet, e- signature).

\section{Conclusions}

The studies allow the conclusion that the level of ICT use in the Silesian region among the key KBE stakeholders, such as business, government, and citizen, is not satisfactory and needs improvement. The analysis leads the authors to formulate two important conclusions.

First, the use of ICT and the Internet by companies is not common. They apply Internet technologies primarily to support B2B and B2C relationships. Mostly, Internet technologies are implemented to support marketing activities, primarily to promote the company and its products and to create the image. The direct sales are rarely offered through this channel, namely online stores. The electronic banking is developing pretty well. The use of ICT in the B2E, E2B and E2E relationships is rather low. ICT is most often used for internal correspondence within the company. The relationships with the public authorities are dominated by electronic billing statements sent to ZUS. Quite often companies use the information and various forms placed on the Internet by public administrations. The other areas of e-services are still marginal.

Secondly, the use of ICT and the Internet by citizens may be considered in the Silesian region as widespread, but only in the context of $\mathrm{C} 2 \mathrm{C}$ relationship. Most people use ICT to communicate with friends and family. However, the situation worsens in the $\mathrm{B} 2 \mathrm{C}$ and $\mathrm{C} 2 \mathrm{~B}$ relationships. ICT and the Internet are mainly used to seek tourist information and transport connections, and information about cultural events and entertainment. A large number of people make purchases online, but occasionally. The e-banking is developing fairly well. The worst situation is when it comes to the use of ICT in relations of citizens with the administration. Most people acquire information directly from the office or collect the forms. Only a few citizens communicate with the public administration offices using the Internet in order to acquire information or forms, or to handle administrative matters comprehensively in an electronic way.

The research also made it possible to develop recommendations aimed at increasing the use of ICT in the Silesian region. The most important include the following issues.

First, it is necessary to abolish all barriers to the ICT use. This refers primarily to economic barriers. They are related to the cost of access to ICT (computers, Internet access, servers) and can become a factor of the digital divide for citizens and small and medium-sized companies. Contrary to the general belief, the social status of many citizens and high operating costs of companies often prevent access to ICT. Therefore, it is necessary to take measures to reduce the cost of access to the Internet and ensure the use of it in public places.

Second, there is a need for removing technical barriers that primarily relate to access to the Internet, especially broadband. Hence, without an efficient, high quality and extensive telecommunications infrastructure it is not possible to achieve high KBE growth dynamics in the region. It is necessary to take measures which will result in laying long-lasting infrastructural and institutional foundations for this development. A key role can be played here by the control of the inventory and modernization of the existing data communication networks (offered by various telecommunications companies), coordination of activities related to their development, and the development of new solutions based on uniform standards.

Third, it is necessary to support activities aimed at increasing the intensity of competition in the ICT area in the Silesian Voivodship. The region's significant resources (e.g., road infrastructure, universities, research and development centres, and sizeable population) should be exploited. 
The Use of ICT for Economic Development in Silesian Region in Poland

Finally, it is necessary to promote the idea of $\mathrm{KBE}$ and support the development of competences of companies and citizens that are essential for the effective use of ICT.

\section{References}

Anumba, C. J., \& Ruikar, K. (2008). e-Business in construction. Oxford: John Wiley \& Sons.

Araya, D., \& Peters, M. (Eds.). (2010). Education in the creative economy. New York: Peter Lang.

Bangemann, M. (1994) Bangemann Report. Europe and the global information society. (1994). Retrieved October 29, 2008, from http://ec.europa.eu/idabc/servlets/Doc?id=18174

Bell, D. (1973). The coming of post-industrial society: A venture in social forecasting. New York: Basic Book.

Castells, M. (1997). The information age: Economy, society and culture. The Rise of Network Society. Vol. 2. Oxford: Blackwell Publishers.

Castells, M., \& Himanen, P. (2002). The information society and the welfare state. The Finnish model. Oxford: Oxford University Press.

Cohendet, P., \& Stojak, L. (2005). The digital divide in Europe. The economic and social issues related to "Knowledge-Based Europe". Futuribles: Analyse et Prospective, 305, 5-28.

Collis, J., \& Hussey, R. (2003). Business research. New York: Palgrave Macmillan.

Cooke P., \& Leydesdorff, L. (2006). Regional development in the knowledge-based economy: The construction of advantage. The Journal of Technology Transfer, 31(1), 5-15.

Creswell, J. W. (1994). Research design: Qualitative and quantitative approaches. Thousand Oaks: Sage.

David, P. A., \& Foray, D. (2002). An introduction to the economy of the knowledge society. International Social Science Journal, 54(171), 9-23.

Drucker, P. F. (1993). Post-capitalist society. New York: Harper Business.

Ein-Dor, P., Myers, M., \& Raman, K. S. (2004). IT industry and the knowledge economy: A four country study. Journal of Global Information Management, 12(4), 23-49.

Europa. (2000). eEurope. An information society for all. Retrieved November 252010 from: http://europa.eu/legislation_summaries/information_society/124221_en.htm

Europa. (2005). i2010. A European information society for growth and employment. Retrieved December 1 2010 from http://europa.eu/ legislation_summaries/information_society/c11328_en.htm

Godin, B. (2006). The knowledge-based economy: Conceptual framework or buzzword? The Journal of Technology Transfer, 31(1), 17-30.

Goeransson, B., \& Soederberg, J. (2005). Long waves and information technologies. On the transition towards the information society. Technovation, 25(3), 203-211.

Hanna, N. K. (2009). e-Transformation: Enabling new development strategies. New York: Springer.

Hanna, N. K. (2010). Enabling enterprise transformation. Business and grassroots innovation for the knowledge economy. New York: Springer.

Hayek, F.A. (1937). Economics and knowledge. Economica, IV, 33-54. Retrieved March 10, 2011, from http://www.virtualschool.edu/mon/Economics/HayekEconomicsAndKnowledge.html

Hayek, F.A. (1945). The use of knowledge in society. American Economic Review, 35(4). Retrieved March 10, 2011, from http://www.econlib.org/library/Essays/hykKnw1.html

Kassicieh, S. K. (2010). The knowledge economy and entrepreneurial activities in technology-based economic development. Journal of the Knowledge Economy, 1(1), 24-47. 
Leydesdorff, L. (2006). The knowledge-based economy: Modeled, measured, simulated. Boca Raton: Universal Publishers.

Meier, A., \& Stormer, H. (2009). eBusiness \& eCommerce. Managing the digital value chain. Berlin: Springer-Verlag.

Melnikas, B., \& Samulevičius, J. (2009). Knowledge-based economy in the European Union: Creation, process, the main topicalities and problems of clusterization. European Integration Studies. Research and Topicalities, 3, 112-220.

MNiI. (2005). Strategia kierunkowa rozwoju informatyzacji Polski do roku 2013 oraz perspektywiczna prognoza transformacji spoleczeństwa informacyjnego do roku 2020 Warszawa: Ministerstwo Nauki i Informatyzacji.

MSWiA. (2008). Strategia rozwoju społeczeństwa informacyjnego w Polsce do roku 2013. Warszawa: Ministerstwo Spraw Wewnętrznych i Administracji. Retrieved November 252010 from: http://www.mswia.gov.pl/strategia/.

OECD. (1996). Special theme: The knowledge-based economy. In Science, Technology and Industry Outlook. Paris: OECD.

Olszak, C. M., \& Ziemba, E. (2009). The information society development strategy on a regional level. Issues in Informing Science and Information Technology, 6, 213-225. Retrieved from http://iisit.org/Vol6/IISITv6p213-225Olszak618.pdf

Porter, M. E. (1985). Competitive advantage: Creating and sustaining superior performance. New York: A Division of Simon \& Schuster.

Rivard, S., Aubert, B. A., \& Patry, M. (2004). Information technology and organizational transformation. Solving the management puzzle. New York: Elsevier.

Roztocki, N., \& Weistroffer, H. R. (2009a). Information and communications technology in developing, emerging and transition economies: An assessment of research. Proceedings of the Fifteenth Americas Conference on Information Systems. San Francisco, August 6-9. Retrieved November 252010 from: http://papers.ssrn.com/sol3/papers.cfm?abstract id $=1457435$

Roztocki, N., \& Weistroffer, H. R. (2009b). Research trends in information and communications technology in developing, emerging and transition economies. Collegium of Economic Analysis, 20, 113-127. Retrieved November 252010 from http://papers.ssrn.com/sol3/papers.cfm?abstract id=1577270

Skyrme, J. D. (1999). Knowledge networking: Creating the collaborative enterprise. Oxford: Butterworth Heinemann.

Smith, J. K. (1983). Quantitative versus qualitative research: An attempt to clarify the issue. Educational Researcher, 12(3), 6-13.

Steinmueller, W. E. (2002). Knowledge-based economies and information and communication technologies. International Social Science Journal, 54(171), 141-154.

Tapscott, D., \& Williams, A. D. (2006). Wikinomics: How mass collaboration changes everything. New York: Penguin Group.

Toffler, A. (1980). The third wave. New York: Bantam Books.

World Bank. (2009). The knowledge-based economy. A brief overview with emphasis on the MENA region. Retrieved from http://info.worldbank.org/etools/docs/library/252519/Session2_JFR.pdf

World Bank. (2011). Knowledge for development. KEI and KI indexes. Retrieved from http://info.worldbank.org/etools/kam2/KAM page5.asp 


\section{Appendix A. The Use of ICT (Internet) in the Silesian Companies - the Questionnaire}

Question 1. What are the areas of ICT use in the company?

\begin{tabular}{|c|c|c|c|c|c|c|}
\hline \multirow[b]{2}{*}{ No. } & \multirow[b]{2}{*}{ Specification } & \multirow[b]{2}{*}{$\begin{array}{l}\text { The issue } \\
\text { does not } \\
\text { concern } \\
\text { my com- } \\
\text { pany }\end{array}$} & \multirow[b]{2}{*}{$\begin{array}{c}\text { The com- } \\
\text { pany uses } \\
\text { the Inter- } \\
\text { net }\end{array}$} & \multicolumn{2}{|c|}{ The company uses } & \multirow{2}{*}{$\begin{array}{c}\text { The } \\
\text { company } \\
\text { is not } \\
\text { capable } \\
\text { of deal- } \\
\text { ing with } \\
\text { the issue }\end{array}$} \\
\hline & & & & $\begin{array}{l}\text { paper and } \\
\text { pencil }\end{array}$ & $\begin{array}{l}\text { computer and } \\
\text { software }\end{array}$ & \\
\hline
\end{tabular}

B2E, E2B, and E2E relations

\begin{tabular}{|l|l|l|l|l|l|l|}
\hline 1 & $\begin{array}{l}\text { Correspondence (e.g. bulletins, notice } \\
\text { boards and e-mails) }\end{array}$ & & & & & \\
\hline 2 & Passing official orders & & & & & \\
\hline 3 & Exchange of knowledge and experience & & & & & \\
\hline 4 & $\begin{array}{l}\text { Conducting routine procedures (e.g. } \\
\text { business trips, holiday leave applica- } \\
\text { tions) }\end{array}$ & & & & & \\
\hline 5 & Horizontal cooperation & & & & & \\
\hline 6 & Vertical cooperation & & & & & \\
\hline 7 & Social integration & & & & & \\
\hline
\end{tabular}

\section{B2B relations}

\begin{tabular}{|l|l|}
\hline 8 & Searching for business partners and
\end{tabular}

8 negotiations

9 Sending and receiving offers

\begin{tabular}{|l|l|}
\hline 10 & Ordering \\
\hline 11 & Receipt 0 o \\
\hline
\end{tabular}

\begin{tabular}{l|l}
11 & Receipt of orders \\
\hline 12 & Issuing invoices
\end{tabular}

12 Issuing invoices

\begin{tabular}{ll}
13 & Receiving invoices \\
\hline 14 & Settlement of payables
\end{tabular}

\begin{tabular}{|l|l}
\hline 14 & Settlement of payables \\
\hline 15 & Settlement of receivables \\
\hline
\end{tabular}

15 Settlement of receivables

16 The exchange of experience and knowledge

\section{A2B and B2A relations}

17 Sending tax return forms to tax authori-

17 ties

18 Exchange of correspondence with tax

authorities

19 Settling tax liabilities

20 Communication with customs authori-

20 ties

21 Sending ZUS returns

22 Exchange of correspondence with ZUS

23 Settlement of social insurance liabilities

24 Communication with city, municipal or

24 county offices

25 Access to the Internet Public Informa-

tion Bulletin

The primary and support activities of a company

\begin{tabular}{|l|l|l|l|l|l|l|}
\hline 26 & Purchasing & & & & & \\
\hline 27 & Sales & & & & & \\
\hline 28 & Inventory service & & & & & \\
\hline 29 & Human Resources & & & & & \\
\hline 30 & Payroll & & & & & \\
\hline 31 & Marketing & & & & & \\
\hline 32 & Finance and accounting & & & & & \\
\hline 33 & Manufacturing & & & & & \\
\hline 34 & Transport & & & & \\
\hline
\end{tabular}




\begin{tabular}{|l|l|l|l|l|l|l|}
\hline Economic and financial analysis & & & & & \\
\hline 35 & Quality control & & & & & \\
\hline 36 & Business processes audit & & & & & \\
\hline 37 & Investments audit & & & & & \\
\hline 38 & Market analysis & & & & & \\
\hline 39 & Product/service analysis & & & & \\
\hline 40 & $\begin{array}{l}\text { Environmental scanning (economic, } \\
\text { political, social factors) }\end{array}$ & & & & & \\
\hline
\end{tabular}

Question 2. What ICT are used by the company?

\begin{tabular}{|c|c|c|c|c|c|}
\hline \multirow[b]{2}{*}{ No. } & \multirow[b]{2}{*}{ ICT category } & \multirow[b]{2}{*}{ Uses } & \multicolumn{3}{|c|}{ Does not use } \\
\hline & & & but intends & $\begin{array}{l}\text { there is no } \\
\text { such a need }\end{array}$ & $\begin{array}{c}\text { does not } \\
\text { know }\end{array}$ \\
\hline 1 & E-mail & & & & \\
\hline 2 & Database (e.g. Access) & & & & \\
\hline 3 & Text editors (e.g.. Microsoft Word) & & & & \\
\hline 4 & Spreadsheets (e.g. Microsoft Excel) & & & & \\
\hline 5 & Graphics editor (e.g. Corel Draw, Photoshop) & & & & \\
\hline 6 & Search engines (e.g. Google) & & & & \\
\hline 7 & Electronic newsletters and bulletins & & & & \\
\hline 8 & Discussion forums & & & & \\
\hline 9 & Social networks & & & & \\
\hline 10 & Teleconferences & & & & \\
\hline 11 & Instant Messengers (e.g. GG, Skype) & & & & \\
\hline 12 & Intranet & & & & \\
\hline 13 & Extranet & & & & \\
\hline 14 & Content management systems (CMS) & & & & \\
\hline 15 & Online analytical processing OLAP & & & & \\
\hline 16 & Data mining & & & & \\
\hline 17 & Data warehouse & & & & \\
\hline 18 & Business Intelligence & & & & \\
\hline 19 & Enterprise resource planning systems (ERP) & & & & \\
\hline 20 & Document management systems & & & & \\
\hline 21 & Workflow systems & & & & \\
\hline 22 & Others (specify) & & & & \\
\hline
\end{tabular}

Question 3. Does the company have an electronic signature?

- yes, the qualified electronic signature

- yes, the non-qualified electronic signature

- no

Question 4. Why does the company not have an electronic signature?

- there is no such a need

- low prevalence in the use of

- too expensive

- other (specify) 
Question 5. What does the company use an electronic signature for?

- for communication with banks

- to communicate with ZUS (a social insurance institution)

- to communicate with tax authorities

- for communication with the offices of the city, municipal, county

- to communicate with contractors

- differently (how?) other (specify)

Question 6. What constitutes a barrier to the use of ICT in the company?

- lack of information about the existence of relevant services

- lack of appropriate services

- lack of skills of workers

- lack of technological conditions

- high cost (the Internet access, computers, software, e-signature)

- others (which?)......

\section{Appendix B. The Use of the Internet by Citizens in the Silesian Region - the Questionnaire}

Question 1. How often do you use the Internet?

- daily

- several times a week

- several times a month

- occasionally

Question 2. Where do you use the Internet?

- home

- at he university/school

- at work

- Internet cafe

- other

Question 3. What tools do you use to communicate?

- e-mail

- instant messaging

- forums and discussion groups

- chat rooms

- $\quad$ social networking sites

- Internet telephony (VoIP)

- Blogs

- others (specify)

Question 4. What ICT do you use for you search for information and services?

- e-mail

- search engine

- professional services

- BIP (Public Information Bulletin)

- price comparison 
Question 5. What do you use the Internet for?

\begin{tabular}{|l|l|l|l|l|}
\hline No & Services & $\begin{array}{c}\text { ICT (Internet) } \\
\text { use }\end{array}$ & $\begin{array}{c}\text { Do not use ICT } \\
\text { (Internet) }\end{array}$ & No answer \\
\hline 1 & Public e-services & & & \\
\hline 2 & Shopping & & & \\
\hline 4 & Information on medical services & & & \\
\hline 5 & Tourist information & & & \\
\hline 6 & Banking and financial services & & & \\
\hline 7 & Legal advice & & & \\
\hline 8 & $\begin{array}{l}\text { Information on cultural events and entertain- } \\
\text { ment }\end{array}$ & & & \\
\hline 9 & Information about transport connections & & & \\
\hline 10 & Vocational and skills improvement training & & & \\
\hline 11 & $\begin{array}{l}\text { Information on vocational skills enhancing } \\
\text { training }\end{array}$ & & & \\
\hline 12 & Provision of jobs & & & \\
\hline 13 & Information on job opportunities & & & \\
\hline 16 & Information on medical services & & & \\
\hline
\end{tabular}

Question 6. How do you use the Internet in relations with the public administration?

- gaining information from the office

- downloading the application forms from the office

- passing information to the office

- $\quad$ sending forms to the office

- comprehensive electronic way of a master settling

- official matter monitoring

- others (specify)

Question 7. How often do you buy the following products over the Internet

\begin{tabular}{|l|l|l|l|l|}
\hline No & \multicolumn{1}{|c|}{ Description } & Very often & Sometimes & Never \\
\hline 1 & tickets (airline, train, concert, cinema, etc) & & & \\
\hline 2 & jewelry & & & \\
\hline 3 & cosmetics & & & \\
\hline 4 & books & & & \\
\hline 5 & clothing / footwear & & & \\
\hline 6 & software & & & \\
\hline 7 & CDs / music / video & & & \\
\hline 8 & computer hardware & & & \\
\hline 9 & brown/white goods & & & \\
\hline 10 & automotive articles & & & \\
\hline 11 & mobile phones / accessories & & & \\
\hline 12 & toys & & & \\
\hline 13 & food & & & \\
\hline 14 & Other (specify) ................. & & \\
\hline
\end{tabular}


Question 8. Does you have an electronic signature?

- yes, the qualified electronic signature

- yes, the non-qualified electronic signature

- no

Question 9. Why does you not have an electronic signature?

- there is no such a need

- low prevalence in the use of

- too expensive

- other (specify)

Question 10. What creates a barrier to you the Internet use?

- lack of information about the existence of relevant services

- lack of appropriate services

- lack of skills

- lack of technological conditions

- high cost (the Internet access, computers, software, e-signature)

- others (which?)......

\section{Biographies}

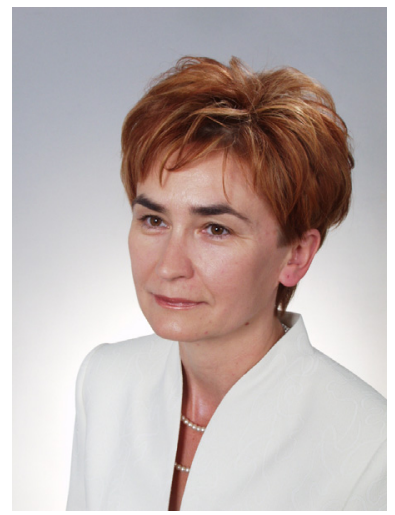

Celina M. Olszak is a Professor of Management Information Systems at University of Economics in Katowice, Poland. She is Chair of the Department of Business Informatics and Vice-Dean in Charge of Research at the Faculty of Economics. She was scholarship holder at Swiss Federal Institute of Technology in Zurich, Switzerland and scholarship holder of Deutsche Akademische Austausch Dienst at Trier University in Germany.

She has published numerous articles in the areas of information systems, decision support systems, systems development strategies. Her current research interests include knowledge management, Business Intelligence Systems, e-business and information society. She is a member of Informing Science Institute in California, USA.

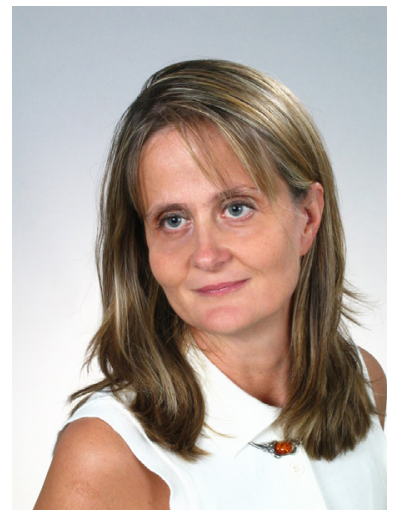

Ewa Ziemba is an Associate Professor of Management Information Systems at the University of Economics in Katowice, Poland. She is an author of numerous articles published in journals, conference proceedings and as book chapters. She has written five books on e-business systems, web designing, corporate portals for knowledge management and information society. Her current research concentrates mostly on e-business, information society and information systems for knowledge management, especially designing corporate portals for knowledgebased organizations.

She has participated in several European research projects relating to e-business systems and e-learning. Her academic qualifications have been combined with practical experience - she has been working as the IT Project Manager for over ten years. Furthermore, she is a member of Informing Science Institute in California, USA. 